\title{
Immunologic Features of Graves' Disease in Obese Patients
}

\author{
Fishman $\mathrm{B}^{1}$, Zurabov $\mathrm{V}^{1}$, Kuprin $\mathrm{P}^{1}$, Rumyantsev $\mathrm{Y}^{1}$, Nedvetskaya \\ $\mathrm{E}^{1}$, Turmakhanov $\mathrm{S}^{2}$, Butrimova $\mathrm{S}^{2}$, Lole $\mathrm{O}^{3 *}$ and Yukhno $\mathrm{M}^{3}$ \\ ${ }^{1}$ Yaroslav-the-Wize Novgorod State University, Institute of Medical Education, Veliky \\ Novgorod, Russia \\ ${ }^{2}$ Regional Clinical Hospital, Veliky Novgorod, Russia \\ ${ }^{3}$ Central City Clinical Hospital, Veliky Novgorod, Russia
}

\section{Research Article}

Volume 2 Issue 11

Received Date: October 06, 2018

Published Date: October 12, 2018

*Corresponding author: Oksana Lole, Head of Therapeutic Department of the Central City Clinical Hospital, postgraduate student of the Novgorod state University, Russia, Email: oji86ego1@mail.ru

\section{Abstract}

The data presented in the article indicate significant changes in the hormonal background in obese patients with thyroid gland diseases. Various systems are involved: lipid changes in the liver, impaired synthesis and production of thyroid hormones and adrenal glands hormones. More than 30\% of the operated patients with Graves' disease (GD) have obesity of various degrees. Moreover, after surgical treatment of GD, there was a decrease in body weight by 1.3-1.5 times without specific therapy. At the same time, the volume of surgical intervention was regulated individually, including taking into account obesity. The volume of thyroid residue was $3-4 \mathrm{~cm}^{3}$ of gland tissue. In the postoperative period, replacement therapy with L-thyroxine 75-250 mg was administered (the dose was adjusted under the control of $\mathrm{T}_{3}, \mathrm{~T}_{4}$, TSH in the blood).

Keywords: Graves' Disease; Obesity; Adrenal Hormones; Thyroid Gland; Antibodies; Autoimmunization

\section{Introduction}

Prevention, diagnosis and treatment of diseases of the thyroid gland is of utmost importance among the most pressing problems of clinical endocrinology [1-3]. Graves' disease (GD) is the most frequent disease both among thyroid diseases (thyroid gland) and in the structure of all endocrine diseases. The etiology of this disease is not well understood. In the pathogenesis of GD, autoimmune thyroid lesion is of particularly important [4-10]. Excessive production of hormones in GD is due to stimulation of receptors for TSH located on the surface of thyrocytes, as well as antibodies, known as thyrostimulating [4-6,10-13]. Currently, GD is regarded as a genetic disease of an autoimmune nature, caused by a congenital defect in the immune system $[4,5]$.

An association of hyperthyroidism with obesity has been observed in both women and men in the early and mature age $[1,8,14]$. Moreover, it should be noted that the factors leading to obesity can themselves trigger the early development of hyperthyroidism, and also can lead to late decompensation of hyperthyroidism. Thus, not only hormonal disorders associated directly with thyroid gland, but also the adrenal-thyroid system as a whole must be studied. ACTH, acting on the adrenal cortex, 


\section{Virology \& Immunology Journal}

accelerates the production of steroid hormones (cortisol and small amounts of androgens and estrogens), maintaining the adrenal mass at a normal level, stimulating mainly the synthesis of cortisol, whose reserves in the adrenal glands are insignificant. ACTH stimulates the breakdown of fat in adipose tissue, the absorption of amino acids and glucose by muscle tissue, the release of insulin from $\beta$ - cells of the pancreas, contributing to the development of hypoglycemia $[15,16]$.

Cortisol is involved in many metabolic processes and plays a key role in the body's defensive reactions to stress and hunger. For example, in hunger cortisol provides a normal level of glucose in the blood. Increased cortisol levels are common in obese people. C-reactive protein (CRP) is a classic laboratory marker of inflammation and damage. A moderate increase in the level of CRP in the plasma reflects not so much the severity of atherosclerosis as the chronic subclinical inflammation of the vascular endothelium, which, in turn, plays a very significant role in the development of atherothrombosis. Cortisol is involved in many metabolic processes and plays a key role in the body's defensive reactions to stress and hunger. Increased cortisol level is common in obese people.

\section{Methods}

Analyzed 561 patients admitted with GD to the therapeutic and surgical departments of the Novgorod regional and central clinical hospitals of Veliky Novgorod from 1997 to 2016. The comparison group included 49 patients $(75.5 \%)$ women and $(24.3 \%)$ men from the therapeutic department of the Novgorod Central City Clinical Hospital with arterial hypertension and obesity without the clinical manifestations of thyroid disease. Blood levels of insulin, C-peptide, ACTH, morning and evening cortisol, antibodies to thyroperoxidase (TPO-AB), thyroid hormones $\left(\mathrm{T}_{3}, \mathrm{~T}_{4}\right)$ and thyroid stimulating hormone (TSH) were studied. Out of 561 patients with GD, $172(30.7 \%)$ were admitted with obesity, including $112(65.1 \%)$ women and 60 (34.9\%) men or $28.8 \%$ of the admitted women and $34.9 \%$ men. These patients were admitted for surgical treatment for GD. Moreover, in some patients, obesity developed on the background of longterm treatment of GD, in others, obesity preceded manifestations of hyperthyroidism. Hormone blood levels were studied in 90 patients.

Same blood hormone levels were measured in 90 patients with GD (60 women and 30 men). Body mass index by Ketle was calculated, and blood levels of insulin (mmol / l), C-peptide (ng / ml), cortisol (nmol / l) morning and evening, ACTH (nmol / l), antibodies to thyroid peroxidase (TPO-AB) (U / l), lipoproteins, CRP. $90 \%$ of men were aged $20-49$ years, women of this age group made up $56.3 \%$ of their total number, while at the age of 50 years and older women were $42.9 \%$; men over 50 years old $-8.2 \%$. The average age of women was $38.4 \pm$ 1.5 years, men $31.4 \pm 2.6$.

StatSoft Statistica software, ver. 10.0.A was used for calculations (serial number axxr107b21840fa). Statistical significance was stated at $\mathrm{p}<0.05$.

\section{Results}

Patients of the study group of with GD had an increase in the thyroid gland size to I-II degree, $43(25.0 \%)$ had an increase to the II degree, of which women $-23(20.5 \%)$, men - 22 (36.7\%). Thyroid gland palpation results usually showed a soft-elastic consistency in patients with GD. In 69 patients $(40.1 \%)$, the thyroid gland was more dense and heterogeneous in consistency, of which 32 (28.6\%) women and 39 (65.0\%) men. In 30 (17.4\%) cases, nodes were detected with a diffuse increase in the thyroid gland, of which 15 (13.4\%) women and 16 (26.7\%) men.

Expressed exophthalmos from 172 patients was in 86 (50.0\%), including $42(70.0 \%)$ men and $47(42.0 \%)$ women. Moderate exophthalmos was observed in 30 $(17.4 \%)$ patients, of them in $13(22.7 \%)$ men and 17 $(15.2 \%)$ women.

As for GD severity, a mild degree was detected in 21 patients $(13.4 \%$ among all patients and $18.7 \%$ among women), there were no men among them. The main number were patients with moderate severity - 116 (67.4\%), including 44 men (73.3\% among all men) and 72 women (64.3\% among all women). Severe course was noted in $35(19.8 \%)$ patients, respectively in $16(26.7 \%)$ and $19(17.0 \%)$.

In the compensated state, $34(19.8 \%)$ patients were admitted: 12 (20.0\%) men and $22(19.6 \%)$ women. Subcompensation of hyperthyroidism was detected in $108(62.8 \%)$ patients, of which $34(56.7 \%)$ were men and $74(66.1 \%)$ were women. Decompensation prevailed in men (14-23.3\%) compared with women (16-14.3\%). 


\section{Virology \& Immunology Journal}

\begin{tabular}{|c|c|c|c|}
\hline Indicators & $\mathbf{X}_{\text {med }} \pm$ SD & CI value (25-75\%) & Range \\
\hline Age (years) & $38.4 \pm 1.5$ & $35.0 \div 42.0$ & $31.5 \div 48.3$ \\
\hline Body mass index & $33.8 \pm 0.9$ & $31.0 \div 37.0$ & $31.9 \div 35.7$ \\
\hline SBP (mm Hg) & $158.0 \pm 6.3$ & $145.0 \div 165.0$ & $145.2 \div 170.8$ \\
\hline DBP (mm Hg) & $95.5 \pm 2.7$ & $90.0 \div 100.0$ & $90.1 \div 101.0$ \\
\hline Insulin (mmol/l) & $21.3 \pm 1.9$ & $10.0 \div 31.0$ & $17.5 \div 25.1$ \\
\hline C-peptide (ng/ml) & $4.5 \pm 0.6$ & $2.3 \div 6.0$ & $3.3 \div 5.8$ \\
\hline Morning cortisol (nmol/l) & $597.6 \pm 26.7$ & $472.0 \div 714.3$ & $541.6 \div 633.7$ \\
\hline Evening cortisol (nmol/l) & $257.9 \pm 31.0$ & $134.0 \div 420.0$ & $192.7 \div 323.1$ \\
\hline ACTH (pmol/l) & $5.8 \pm 1.5$ & $4.0 \div 7.0$ & $1.5 \div 10.1$ \\
\hline TSH $(\mu U / l)$ & $6.2 \pm 0.7$ & $3.6 \div 8.0$ & $4.7 \div 7.7$ \\
\hline $\mathrm{T}_{3}(\mathrm{nmol} / \mathrm{l})$ & $3.0 \pm 0.2$ & $1.8 \div 4.2$ & $2.5 \div 3.5$ \\
\hline
\end{tabular}

Table 1: Anthropo physiological indicators and hormonal spectrum in obese women.

The body mass index (BMI) value, regardless of gender, was $33.8 \pm 0.9$, characterizing patients according to the WHO classification (1993), as patients with morbid and severe obesity. 1 year after surgical intervention, out of 90 , only $51(56.7 \%)$ patients were examined. At the same time, there was a tendency to decrease in body weight by 1.3-1.5 times without specific therapy.

Spearman correlation analysis was performed to determine correlations between the development of cardiovascular disease in patients and obesity, regardless of gender. Only those correlations were analyzed for which the critical level of significance was reached $(p$ $<0.05$ ).

In the studied group of patients, the indicators of systolic blood pressure (SBP) and diastolic blood pressure (DBP) were higher than in the control group.
The pulse rate was no more than 100 beats per minute. Without rhythm disturbance, only in a few cases isolated extrasystoles were detected. Rhythm disorders were observed in both women and men. The magnitude of SBP and DBP averaged in women $158.0 \pm 6.3$ and $95.5 \pm$ $2.7 \mathrm{~mm} \mathrm{Hg}$. Art., for men, respectively, $159.2 \pm 4.6$ and $98.8 \pm 3.9$. According to the classification of arterial hypertension, depending on the level of blood pressure (2017), patients can be assigned to the group with hypertension 1 and 2 degrees.

It was found that SBP increased with increasing BMI $(\mathrm{r}$ $=0.41 ; \mathrm{p}=0.0029)$ in the study and control groups. DBP, repeating the changes in SBP $(r=0.73 ; p=0.0001)$, was also associated with an increase in BMI ( $\mathrm{r}=0.56$; $\mathrm{p}=$ 0.0001). The rise in DBP was also correlated with an increase in plasma atherogenicity: with VLDL ( $\mathrm{r}=0.503$; $\mathrm{p}$ $=0.0004)$ and with an atherogenic index $(\mathrm{r}=0.35 ; \mathrm{p}=$ 0.0161).

\begin{tabular}{|c|c|c|c|}
\hline Indicators & $\mathbf{X}_{\text {med }} \mathbf{+ S D}$ & CI value (25-75\%) & Range \\
\hline Age (years) & $31.3 \pm 2.6$ & $30.5 \div 34.8$ & $29.5 \div 45.8$ \\
\hline Body mass index & $33.8 \pm 1.3$ & $31.0 \div 37.5$ & $31.0 \div 36.5$ \\
\hline SBP (mm Hg) & $159.2 \pm 4.6$ & $145.0 \div 172.5$ & $149.0 \div 169.3$ \\
\hline DBP (mm Hg) & $98.8 \pm 3.9$ & $90.0 \div 105.0$ & $90.2 \div 107.3$ \\
\hline Insulin (mmol/l) & $21.1 \pm 2.7$ & $16.0 \div 28.0$ & $15.0 \div 27.2$ \\
\hline C-peptide (ng/ml) & $3.4 \pm 0.5$ & $2.1 \div 4.3$ & $2.3 \div 4.4$ \\
\hline Morning cortisol (nmol/l) & $704.3 \pm 55.9$ & $498.0 \div 803.0$ & $567.6 \div 841.0$ \\
\hline Evening cortisol (nmol/l) & $533.7 \pm 75.8$ & $420.0 \div 580.0$ & $338.8 \div 728.6$ \\
\hline $\mathrm{ACTH}(\mathrm{pmol} / \mathrm{l})$ & $10.7 \pm 1.5$ & $8.4 \div 14.3$ & $6.8 \div 14.5$ \\
\hline $\mathrm{TSH}(\mathrm{mU} / \mathrm{l})$ & $10.5 \pm 2.3$ & $6.5 \div 12.0$ & $4.1 \div 16.9$ \\
\hline $\mathrm{T}_{3}(\mathrm{nmol} / \mathrm{l})$ & $3.1 \pm 0.7$ & $1.6 \div 4.1$ & $2.4 \div 3.7$ \\
\hline $\mathrm{T}_{4}(\mathrm{nmol} / \mathrm{l})$ & $181.5 \pm 11.6$ & $154.4 \div 205.9$ & $150.6 \div 211.1$ \\
\hline $\mathrm{TPO}-\mathrm{AB}(\mathrm{mU} / \mathrm{ml})$ & $307.1 \pm 130.6$ & $65.0 \div 500.0$ & $124.0 \div 626.7$ \\
\hline
\end{tabular}

Table 2: Anthropophysiological indicators and hormonal spectrum in obese women. 


\section{Virology \& Immunology Journal}

Disorder of insulin secretion, as in men and in women (respectively. $21.1 \pm 2.7$ and $21.3 \pm 1.9 \mathrm{mmol} / \mathrm{l}$ ) was observed. Blood level of C-peptide as an indicator of endogenous insulin secretion in women with obesity it exceeds that in men (respectively. $4.5 \pm 0.6$ and $3.4 \pm 0.5$; $\mathrm{p}<0.05)$. This allows us to consider the level of insulin secretion in women is overestimated. This can be confirmed by the fact that, the maximum indicator of the blood glucose level in some women of this group reached 7.2-9.0 mmol / l. whereas for men, it did not exceed 6.9. In total, with an increase in blood glucose above $6 \mathrm{mmol} /$ l, 18 out of 172 patients or $10.5 \%$ (in men, 3 out of 60 or $5 \%$; in women, 15 out of 112 or $13.4 \%$ ). This determines the need for an individual approach to the choice of treatment tactics, taking into account the possibility of developing or present diabetes.

According to our data, the level of ACTH in men is higher (10.7 $\pm 1.5 \mathrm{nmol} / \mathrm{l})$ than in women ( $5.8 \pm 1.5 \mathrm{nmol}$ / l) by almost 2 times. The upper limit of the confidence interval (CI) in women is 10.1 . for men - $14.5 \mathrm{nmol} / \mathrm{l}$. that does not exceed the upper limit of normal (22 nmol / l) in both groups of patients.

\begin{tabular}{|c|c|c|}
\hline Indicator & Men & Women \\
\hline Total cholesterol (mmol/l) & $5.93 \pm 0.12$ & $6.12 \pm 0.18$ \\
\hline LDL cholesterol (mmol/l) & $3.83 \pm 0.11$ & $3.86 \pm 0.13$ \\
\hline LVDL cholesterol (mmol/l) & $0.94 \pm 0.05$ & $0.92 \pm 0.03$ \\
\hline HDL cholesterol (mmol/l) & $1.24 \pm 0.05$ & $1.51 \pm 0.04$ \\
\hline Atherogenic index (U) & $4.14 \pm 0.05$ & $3.51 \pm 0.04$ \\
\hline Fibrinogen (mmol/l) & $3.98 \pm 0.09$ & $3.43 \pm 0.17$ \\
\hline CRP (mmol/l) & $3.78 \pm 0.06$ & $2.46 \pm 0.11$ \\
\hline
\end{tabular}

Table 3: Indicators of lipid metabolism and some markers of inflammation $\left(X_{\text {med }} \pm S D\right)$.

Dyslipoproteinemia, a disorder of the ratio of the main classes of lipids in plasma is the main risk factor for atherosclerosis. Average values of total cholesterol (TCh), low-density lipoprotein cholesterol (LDLCh) and very low density (LVDLCh) atherogenic index as in men and in women exceeded the normative indicators (TCh from 3.1 to $6.5 \mathrm{mmol} / \mathrm{l}$ ), no statistical significance of intergroup differences. Although the level of high-density lipoprotein cholesterol (HDLCh) in both groups was not reduced, the existing tendencies to a higher level of HDLCh and to a lower level of HDLCh in men determined the statistically significant intergroup differences in the atherogenic index (normal - 3.0).
Higher content of inflammatory markers is notable in men: for CRP, the intergroup differences were statistically significant, for fibrinogen - not significant. The level of morning and evening blood cortisol in men in terms of the average value (respectively. $704.3 \pm 55.9$ and $533.7 \pm 75.8$ $\mathrm{nmol} / \mathrm{l}$ ) exceeds the normal (138-635 nmol / l), and in women it stands only for morning cortisol (respectively. $597.6 \pm 26.7$ and $257.9 \pm 31.0$ ). Such changes are typical for high rates of BMI and determine the need for hormonal correction - in men and individually in women. Hypercortisolism in the observed patients did not usually manifest clinically, only in cases of obesity. Treatment was based on the principle of regulation of the function of the thyroid gland.

TSH level is the most sensitive test of thyroid function. Increased TSH levels were observed in both women and men (respectively, $6.2 \pm 0.7$ and $10.5 \pm 2.3 \mathrm{U} / \mathrm{L}$ ), especially in the latter. At the same time, an increase or normal values of thyroid hormones $\left(\mathrm{T}_{3}, \mathrm{~T}_{4}\right)$ were noted. The increase in TSH indices is not only due to the activation of pituitary hormones, but is also determined by the synergistic action of thyroid-stimulating antibodies, increasing the activity of the thyroid function. In the control group in patients with arterial hypertension and obesity, in examining the function of the thyroid gland, the $\mathrm{T}_{3}, \mathrm{~T}_{4}$ and $\mathrm{TSH}$ values were normal.

Autoimmune processes along with the action of TSH can be considered the trigger for stimulation of thyroid hormones, which is confirmed by the high content (in women - 367.6 \pm 101.6. in men - 307.1 $\pm 130.6 \mathrm{U} / \mathrm{ml}$ ) of antibodies to thyroperoxidase (TPO-AB). TPO-AB is an indicator of the aggression of the immune system in relation to its own organism. Thyroid peroxidase provides the formation of the active form of iodine, which is capable of being included in the thyroglobulin iodification process. Antibodies to this enzyme block its activity. The data obtained indicate the presence of an autoimmunization process regardless of gender.

In $48(28.0 \%)$ cases, where signs of obesity were detected before surgery, hormone replacement therapy - L-thyroxine - was added to thyreostatic treatment from 50 to $250 \mathrm{mg}$ / day (the dose was adjusted under the control of $\mathrm{T}_{3}, \mathrm{~T}_{4}, \mathrm{TSH}$ blood levels).

All patients were operated on, they were performed in $98 \%$ of subtotal thyroidectomy, the volume of residual thyroid tissue was 3-4 cm3. Subsequently, after surgery, replacement therapy was continued. 


\section{Summary}

Along with an increase in TSH in patients, AT-TPO activity is noted, especially in men, which indicates autoimmunization with a simultaneous decrease in the activity of thyroid hormones. This determines the need for the correction of hormonal levels, primarily in men and individually in women. A decrease in the content of insulin and C-peptide, indicating the tendency of patients to develop diabetes. An increase in the level of morning and evening cortisol in men and only morning in women was found. This is typical for patients with high body mass index.

Thus, these data indicate significant changes in the hormonal background in patients with obesity in the thyroid pathology with the involvement of various systems in the pathological process due to lipid changes in the liver, impaired synthesis and production of thyroid hormones and adrenal glands. More than $30 \%$ of the operated patients with GD have obesity of various degrees. Moreover, after surgical treatment of GD, there was a decrease in body weight by 1.3-1.5 times without specific therapy. At the same time, the volume of surgical intervention was regulated individually, including taking into account obesity. The volume of thyroid residue was 3-4 $\mathrm{cm}^{3}$ of gland tissue. In the postoperative period, replacement therapy with L-thyroxine $75-250 \mathrm{mg}$ was prescribed (the dose was adjusted under the control of $\mathrm{T}_{3}$, $\mathrm{T}_{4}$, TSH blood levels).

\section{References}

1. Veber V, Kopina M (2004) Bolezni endokrinnoi sistemi I narusheniia obmena veshestv. Velikii Novgorod pp: 20-43.

2. Dedov I, Gerasimov G, Goncharov G (1994) Algoritmi diagnostici, profilaktiki I lesheniia zabolevanii shitovidnoi gelezi M. pp: 64.

3. Privalov V, Vaichulis T, Revina N (2001) Funkcionalnaia aknivnost chitovidnoi gelezi $\mathrm{v}$ bligaishii I otdalennii sroki posle chirurgicheskogo lecheniia diffuznogo toksicheskogo zoba. Siiezd endokrinologov. Cheliabinsk pp: 317-318.

4. Krukova I, Bazarova E, Birukova M (1989) i dr. Tireoidnii antitela pri autoimmunnich zabolevaniiach shitovidnoi gelezi I ich zavisimost ot prisutstviia autoantigenov. Problemi endokrinologii 4: 19-21.

\section{Virology \& Immunology Journal}

5. Kuzmenko A, Shorin U (1991) Immunologicheskie faktori $\mathrm{v}$ patogeneze autoimmunnich zabolevaniq endokrinnich gelez. Problemi endokrinologii 1: 59-64.

6. Rafimbekov D, Kalinin A (1996) Autoimmunii tireoidit. Bichtek pp: 157.

7. Ortega FJ, Moreno-Navarrete JM, Ribas V, Esteve E, Rodriguez-Hermosa JI, et al. (2009) Subcutaneous fat shows higher thyroid hormone receptor-alpha1 gene expression than omental fat. Obesity (Silver Spring). 17(12): 2134-2141.

8. Reinehr T (2010) Obesity and thyroid function. Mol Cell Endocrinol 316(2): 165-171.

9. Reinehr T, de Sousa G, Andler W (2006) Hyperthyrotropinemia in obese children is reversible after weight loss and is not related to lipids. J Clin Endocrinol Metab 91(8): 3088-3091.

10. Duntas LH (2002) Thyroid disease and lipids. Thyroid 12(4): 287-293.

11. Rotondi M, Cappelli C, Leporati P, Chytiris S, Zerbini F, et al. (2010) A hypoechoic pattern of the thyroid at ultrasound does not indicate autoimmune thyroid diseases in patients with morbid obesity. European Journal of Endocrinology 163(1): 105-109.

12. Svare A, Nilsen TI, Bjøro T, Asvold BO, Langhammer A (2011) Serum TSH related to measures of body mass: longitudinal data from the HUNT Study, Norway. Clin Endocrinol (Oxf) 74(6): 769-775.

13. Kalinin A, Parchomichev R (1991) Nekotorie diskussionnii voprosi chirurgii shitovidnoi i okoloshitovidnoi gelez. Zabolevania shitovidnoi i okoloshitovidnoi gelez: Vserossiiskii simpozium po chirurgicheskoi endokrinologii. Charkov pp: 3-4.

14. Xiao-Ian L, Yao B, Med-Li S (2005) zonghua jianyan yixue zazhin. Clin J lab Med 28(10): 1044-1047.

15. Nannipieri M, Cecchetti F, Anselmino M, Camastra S, Niccolini P, et al. (2009) Expression of thyrotropin and thyroid hormone receptors in adipose tissue of patients with morbid obesity and/or type 2 diabetes: effects of weight loss. Int J Obes (Lond) 33(9): 10011006.

16. Rotondi M, Leporati P, La Manna A, Pirali B, Mondello T, et al. (2009) Raised serum TSH levels in patients with morbid obesity: is it enough to diagnose subclinical hypothyroidism? Eur J Endocrinol 160(3): 403-408. 